\title{
Familial, Situational, and Attitudinal Determinants of Third-Birth Intentions and Their Uncertainty
}

\author{
ANNE RUOKOLAINEN, M.Soc.Sc. \\ Department of Sociology, UCLA, USA \\ Department of Sociology, University of Helsinki, Finland \\ IRMA-LEENA NOTKOLA, Ph.D., Researcher \\ Department of Sociology, University of Helsinki, Finland
}

\begin{abstract}
For this study, we used data from the Finnish Woman's Life Course and Family Formation Survey to study the decision to have or not to have a third child among women who had two children. Our results show that almost one half of the respondents in our sample $(n=636)$ desired to have three or more children, but only 19 per cent intended to have a third birth, while 30 per cent were uncertain about their intentions. We also found that a considerable proportion of the respondents had decided to stop childbearing at a lower parity than desired. To study what determines women's decision to have a third child we estimated three logistic regression models of the determinants of third-birth intentions and their uncertainty, separately for all women at parity two and for those who desired to have three or more children. The results indicate that the factors associated with the intention to cease childbearing differ from those associated with the certainty of intention. Familial and attitudinal factors, such as the quality of partnership, genders of the existing children, and family values, were independently associated with women's intentions to continue childbearing after two children or stop at parity two. However, social and economic constraints made women hesitate with regard to their future fertility plans.
\end{abstract}

\section{Introduction}

Despite the low fertility all over the Western world, in no society are fertility rates approaching zero. Instead, the total fertility rate has remained somewhat below two 
children since the late 1960s or early 1970s, and the two-child family has become a prevailing equilibrium in most Western societies (Coleman 1996). Several surveys have revealed, however, a gap between childbearing desires and actual births in low-fertility settings: the average number of children expected or desired tends to be higher than the number of children finally born (e.g., Eurobarometer 1990, NCHS 1997). Since the current low levels of fertility are to large extent caused by a couple's tendency to stop reproduction after their second birth (Coleman 1996; Hoem and Hoem 1989), much of the discrepancy between desired and actual childbirths can be associated with the absence of third and higher-parity births.

Most people still see having their own children as a unique source of personal satisfaction in life, for which there are no real substitutes (Palomba and Moors 1995; Van den Akker et al. 1993). The results by Miller and Pasta (1993) suggest, however, that a small number of children may satisfy many of the motivational needs related to parenthood, whereas desires for more children are less internalized, and thus more subject to non-motivational factors like individual life circumstances and policy influences. In fact, some researchers have stated that economic constraints are rather generally perceived as obstacles to having third- and higher-parity births, even though the constraints of daily life and working outside the home are not, in general, considered barriers for having one or two children (see Palomba and Moors $1995,252)$. In any case, it seems indubitable that, aside from economic factors, things like individual values and attitudes, as well as other personal attributes, play a significant role in childbearing decisions, especially once the normative two children have been attained, and the couple has to decide whether to stop or continue having children.

In this paper, we will focus on women's decisions to have a third child by studying the determinants of childbearing intentions among Finnish women who already had two children. The previous debate concerning birth intentions has focused on the predictive ability of intention questions (e.g., Monnier 1989; Schoen et al. 1999), and spousal agreement and disagreement (Miller and Pasta 1995; Thomson 1997; Thomson and Hoem 1998). Relatively little attention has been given to determinants of birth intentions themselves (however, see Schoen et al. 1997; Wu and Wang 1998). On the other hand, previous research on third births has overwhelmingly emphasized the association of women's educational attainment and labor force participation with the third birth (e.g., Hoem and Hoem 1989; Hoem 1993; Kravdal 1992), while other determinants of third births have been given less attention.

We suppose that a variety of information about women and couples will be needed to better understand their demand for children. It is well possible that financial and structural constraints set limits to a couple's reproductive decisions, and thus it is important to include measures of socioeconomic circumstances in fertility studies when possible. On the other hand, human fertility occurs in family units, and there 
is a lot of evidence that fertility and the family situation are closely connected (e.g., Brien et al. 1999; Lillard and Waite 1993; Vikat et al. 1999). We should also bear in mind that childbearing decisions, where emotions undoubtedly play an essential role, have an important psychological component. In fact, values and attitudes have attained a more prominent place in the explanations of fertility behavior over the past few decades, and ideational factors have proved to be significant predictors of behavior in the area of family formation (e.g., Lesthaeghe and Moors 1996) as well as other life spheres (Hechter et al. 1999).

A major contribution of our paper to the previous research is an analysis of several situational, familial, and attitudinal determinants of third-birth intentions and their uncertainty. We also pay attention to factors that push women to limit their family size against their will. With this in mind, we analyze the determinants of birthintentions among two-child mothers who desired to have at least three children. Primarily, the results of this study improve our understanding about the antecedents of the decisions to continue or stop childbearing after two children, but they also highlight the role of uncertainty in processes of fertility decision-making.

We use data from the Finnish Family and Fertility Survey of 1989. Upon entering the 1990s, the level of fertility in Finland hovered around the European average, and the total fertility rate varied between 1.7 and 1.8. However, the proportion of Finnish women in the labor force was among the highest in the world. Fully 84 per cent of all married mothers were employed, and almost all employed women worked full-time, with only about 10 per cent working in part-time jobs (Keinänen 1994). At the same time, Finland had a period of general prosperity, and the financial benefits directed to families with small children were generous by international standards. Even though Finnish social policy was not primarily motivated by higher birth rates, but rather by gender equality ideologies and general well-being of children and their families (Rønsen 1998; Forssen 1998, 22-25), it is possible that these benefits indirectly affected the decisions that parents made regarding the size of their family.

This paper will proceed as follows. First, in Section 2, we review literature about birth intentions and consider the relationship between childbearing intentions and desired family-size. Section 3 describes the data, introduces and justifies covariates, and discusses the methods used in the analyses. Results are presented in Section 4, where we first display some descriptive information about birth intentions, and illuminate the relationship between desired family size and intended childbearing. After that we estimate three logistic regression models of the determinants of thirdbirth intentions and their uncertainty, separately for all women at parity two and for those who desired to have three or more children. The last section discusses the meaning and importance of the findings and presents conclusions. 


\section{Birth Intentions}

Miller and Pasta have identified a general psychological sequence that leads to conception and other fertility events. In this sequence, childbearing motivations lead to desires, which lead to intentions, which in turn lead to various instrumental behaviors - i.e., pregnancy seeking or contraceptive behavior - and achievement or avoidance of different fertility outcomes (see Miller and Pasta 1993; 1995).

Childbearing motivations are unconscious states, which are based on both biological capacities and the life experiences of the individual. When these traits are activated in the conscious mind, they are experienced as childbearing desires. Desires represent what the individual himself or herself wants - they are wishes, and as such do not lead directly to action. Rather, they are first translated into intentions, which are conscious commitments to act in a certain way or try to achieve a certain goal in the future. Intentions are different from desires in that they are expressed in relation to the actual childbearing context. In other words, they incorporate the economic and social constraints of current reality that may prevent simply doing what one desires. Under appropriate conditions, intentions of sufficient intensity are translated into instrumental behaviors, which aim to implement the conscious goal. (Miller and Pasta 1995).

Most research on childbearing intentions has used models similar to those used to analyze actual births. However, unlike births (which either occur or do not occur), intentions to have more children are more diverse: fertility intentions are predictions about the future, and they usually contain considerable uncertainty (see Morgan 1981 and 1982; Schoen et al. 1999; Thomson and Hoem 1998; Wu and Wang 1998). Thus, an adequate understanding and analysis of fertility must incorporate this dimension.

S. Philip Morgan $(1981 ; 1982)$ has argued that uncertainty about one's parityspecific intention arises after one has attained a minimal acceptable number of children, but when an additional child would not necessarily be unacceptable. Before attaining a minimal acceptable family size, people have no difficulty in stating an intention to have at least one more child, and after passing through the acceptable range, they can firmly state that they will not have another. Hence, uncertainty in childbearing can be viewed as a transitional stage between childbearing and postchildbearing stages of the reproductive life cycle.

We view the family formation process as sequential, which means that at any time a couple considers rather the having of the next child than their final number of children. The sequential decision-making model is essentially rooted in rational choice theories, where attitudinal, contextual, and socio-demographic considerations 
are combined with the logic of micro-economics (Yamaguchi and Ferguson 1995). It is assumed that an individual makes a fertility choice based on perceived satisfactions and costs of the next child (e.g., Beckman 1978), and that births of different parities are influenced by a different set of circumstances (Namboodiri 1983; White and Kim 1987). These circumstances include, for example, the family as a group, the wife's career prospects and aspirations, as well as the family's current and foreseeable economic situation.

According to the sequential theory, intentions concerning future childbearing may be revised in accordance with changing life circumstances, and intentions can fail to be realized because of various unpredictable factors. Several studies have confirmed, however, that fertility intentions provide fairly accurate forecasts of subsequent fertility (Miller and Pasta 1995; Schoen et al. 1999; Thomson and Hoem 1998), and particularly women who say they intend not to have more children are highly trustworthy (Monnier 1989). Regardless of the fact that the inconsistency between intentions and subsequent behavior may appear to be disappointing from the point of view of forecasting, we think that that birth intentions cast much light on the process of family planning and childbearing decision-making. If we wish to understand the role of uncertainty in fertility decision-making processes or obtain information about the factors, which prevent families from realizing their familysize preferences, studying intentions together with childbearing desires certainly is more useful than studying only actual childbearing. Recent literature has established, moreover, that knowledge of individual fertility intentions adds significant information to fertility models not contained in other predictor variables (Schoen et al. 1999).

\section{Data and Methods}

\section{The sample}

We use data from the Finnish Woman's Life Course and Family Formation Survey undertaken by Statistics Finland at the end of 1989. For the survey, a simple random sample $(\mathrm{n}=5,105)$ of all Finnish women born between 1938 and 1967 was drawn from the Population Registry of Finland. These women were 22-51 years old at the end of 1989, when the data was collected. A total of 4,155 women, i.e., 81.4 per cent of the sample, were personally interviewed at the respondent's home or other undisturbed place.

Except for some descriptive analyses, our interest was in third births, and we restricted the sample to respondents who had two children of their own at the time of the survey. The analyses were further restricted to women who were married or cohabiting at the time of the interview, because childbearing is strongly connected 
to partnership, and planning for childbearing is undoubtedly more topical for women who live in a partnership than for single women. Respondents who were over 39 years old, pregnant, sterilized, or who could not conceive for medical reasons were not asked the question about childbearing intention and could not thus be included in the sample. However, we included pregnant women $(n=22)$ among those intending to have a third child. The final sample used in the analysis comprised 636 women.

\section{Dependent variable}

The main dependent variable used in the analyses was the intention to have a third child. Fertility intentions were measured by the question, 'Do you plan to have another child in the future?' Response options were: yes, unsure, no, and don 't know. We combined the women who gave the 'unsure' or 'don't know' response to a category of 'uncertain'. All women who gave the 'no' response were further asked, 'Could any changes in society or in your private life make you change your mind and make you decide to have another child?'

\section{Covariates}

Our study will highlight four types of independent variables: i) background variables, ii) variables reflecting family composition and family relations, iii) situational factors reflecting the family's social and economic circumstances, and iv) family- and work-related attitude and value-orientation variables. We will start with a discussion about the background variables chosen in the study, and then introduce the other predictors used in the analyses.

Background variables. In a cross-sectional survey, women are interviewed at different stages of their reproductive life. This is reflected in their childbearing intentions, and needs to be taken into account in analysis. In this study, woman's age and age of the second child were included as control variables. We see that in this kind of cross-sectional data the associations of the woman's age and the age of the second child with the intention to have a third child are complicated, and the causal order of variables is difficult to bring out. Although there were no differences in the proportions desiring three or more children in different age groups among all women, the intention to have a third child was more common among younger women with two children than older women with two children. This results from

\footnotetext{
1 This paper focuses entirely on the childbearing intentions of women, because we had no data on men. On the basis of previous studies, however, the degree of consistency at the individual level shows a high level of similarity between husband's and wife's responses to fertility intention questions (Miller and Pasta 1995; Thomson 1997; Thomson and Hoem 1999).
} 
selection during life course. At the beginning of fertile age, the women at parity two include both those who want more than two children and those who don't. At later ages many of those who have wanted more than two children have already had the third child and thus only those who have not wanted more children or whose situational factors have not been favorable for the third child have stayed at parity two. These compositional differences between younger and older women make it difficult to interpret the results concerning the woman's age and time since the second birth. However, these variables may confound the associations that are our focus. Thus, we incorporated these variables as control variables in the explanatory analyses. In the analyses, woman's age was grouped into three classes: 22 to 29 years, 30 to 34 years, and 35 to 39 years. Age of the second child was categorized into four groups: less than 3 years, 3 to 5 years, 6 to 8 years, and 9 years or more.

We used woman's educational attainment as a measure of her socio-economic situation. It was divided in three categories on the basis of the highest educational achievement: basic ( 9 years of education), secondary (10 to 12 years), and tertiary (at least 13 years). We used educational attainment as a control variable as well, because we see that we are not able to study the causal relationship between woman's schooling and her future childbearing plans with cross-sectional data. This matter will be discussed in more detail in connection with findings.

Familial determinants. Earlier studies have found important effects of parents' childbearing behavior on their children's childbearing preferences and behavior (see Axinn et al. 1994). In this paper we studied how the number of the woman's own siblings affects her plans to have a third birth. In accordance with previous studies, we assume that children attempt to recreate their families of origin when making their own fertility decisions. Hence, we hypothesize that having no siblings or only one sibling was associated with the decision to stop childbearing at the second parity, whereas women with two or more siblings were more inclined to have a third birth.

Recent research has demonstrated the negative influence of cohabitation on fertility (Berinde 1999; Brien et al. 1999; Wu and Wang 1998). Marital status was thus included in this analysis as a predictor of birth intentions. Even though the proportion of births to cohabiting couples was rapidly increasing in Finland at the turn of the 1990s, we expect that married mothers were more willing to have an additional birth than those living in consensual unions.

A previous study from Finland has shown that families with an unbalanced gender composition of children prefer a subsequent birth of the opposite gender, because they have a third child more often than families with one boy and one girl (Kartovaara 1999). We included the sex of the previous children in the analyses categorized into three groups: one girl and one boy, two girls, and two boys. 
The previous literature has indicated that many couples view a shared biological child as an important symbol of their marital union (Vikat et al. 1999). To inspect whether the intention to have an additional birth was different between women who did or did not have shared children with their current partner, we constructed the shared children variable. If the respondent's youngest child was born before the date she moved in with her current partner, we concluded that the existing children were from a previous union, and that no children were 'shared' with her partner. We expect that the desire for a third child would be higher among women whose first two children were born before the current union than among women whose spouse was the father of the existing children.

Lillard and Waite (1993) have suggested that chances that the union will last may affect a couple's willingness to make a long-term commitment to the relationship by having children. The chances of disruption may deter the third birth even more than two earlier births once the norm of two children has been reached (see Namboodiri 1983). We included a measure of the quality of spousal relationship in this research. This variable indicates to what extent the spouse understood and knew the respondent's feelings and preferences. If the spouse understood these feelings and preferences extremely well or quite well, spousal relationship was coded as 'good', and if he understood them moderately well, poorly or extremely poorly, spousal relationship was coded as 'dissatisfactory'.

Situational determinants. Family's economic situation is likely to be one of the most important factors affecting a couple's future childbearing plans, especially when making decisions about higher parity births. A variable indicating respondents' satisfaction with the family's financial situation was thus included in this study. A seven-point scale, score 7 representing full satisfaction, and score 1 representing full dissatisfaction, was divided into three categories: 'satisfied' (scores 6 and 7), 'average' (scores 3 to 5), and 'dissatisfied' (scores 1 and 2). Since childrearing is economically expensive, we expect that women who found their financial situation satisfactory could better afford an additional birth, and therefore intended to have a third child more often than women who saw their economic situation as dissatisfactory. Unfortunately, we lack information about the respondents' or their spouses' real income or financial circumstances.

We also examined the role of two other situational factors in the determination of third-birth decisions, namely satisfaction with family benefits and problems with children's day-care arrangements. It must be noted that at the time of the data collection, the financial benefits directed to families with small children were rather generous in Finland. The paid time out of work in connection with birth totaled 44 weeks, and the income compensation covered 70 to 80 per cent of the salary (Rønsen 1998). Parents were also entitled to a home-care allowance after the expiration of paid parental leave. Home-care allowance gave parents an extra 
income transfer to care for their child at home until the child was three years old, and then return to their job. Worth mentioning are the recent large-scale developments in children's day-care facilities as well: in the early 1970s, only about 10 per cent of children under school age had a place in public day-care, while the enrollment included 28 per cent of the $0-6$-year-olds by 1980 , and ten years later the proportion had risen to 45 per cent (Rønsen 1998). The cost of day-care was heavily subsidized by municipalities and the state. Other family benefits included child allowances, tax deductions, and housing allowances, all of which provided significant forms of economic support for families with children.

Satisfaction with family benefits describes the respondent's opinion about the sufficiency of public aid given to families with small children. We created the category of 'sufficient' for women who said that these benefits were totally or rather sufficient. The 'quite insufficient' and 'totally insufficient' answers were combined to one category, 'insufficient'. We assume that women who considered the family benefits sufficient were more willing to have a third birth than women who considered these benefits insufficient.

Respondents were also asked if they have ever had any problems with day-care for their first or second child. If the interviewee expressed at least some problems with day-care, she was categorized as having experienced 'at least some problems'. We hypothesize that experiencing difficulties with day-care arrangements deterred women from having additional children.

Attitudinal determinants. Women's paid work outside home is commonly seen as one of the most significant factors behind low fertility rates. We included two variables reflecting working attitudes in this study. A variable titled meaning of work was used as a measure of respondents' work orientation. Women were shown a list of aspects, which people might find important in their work, and they were asked what they think is the most important. Options were 1) A steady job, so there is no fear of being made redundant or unemployed, 2) A good salary, so there are no money problems, 3) Working with people you like, 4) Having a job where you can help people, 5) Having a job that makes you feel you are achieving something, and 6) Having a job that allows you to develop yourself. We think that the first two options represent a rather instrumental attitude toward work, and we categorized respondents who selected these options to the group 'instrumental'. We interpreted the other options to mean that the content of the work is important for the respondent; these four options were categorized as 'content of work'. As satisfaction received from a career may be an alternative to childrearing and family life, we hypothesize that women who had generally stronger preference for work were less willing to have a third birth than women who took an instrumental view of paid work. 
As shown by Britta Hoem (1993), the most important choice in labor force commitment in Sweden is made after the first birth, and those who become housewives then will often stay outside the labor force for quite a while. In this research, respondent's employment between her first and second birth was used as a measure of her role orientation - we think that a woman's choice of employment status during that period indicates her position on a scale that separates the more family-oriented form the more job-oriented (see Hoem and Hoem 1989). Therefore, we registered whether a respondent was a homemaker all the time between the first two births ('home' category), or whether she was employed at any time between these births ('work'). Because women's labor force participation and low birth rates are usually seen as interdependent, we expect that respondents who were employed between the first two births intended to have a third birth less often than respondents who were homemakers during that period.

Finally, we included three value orientation variables - family values, religiousness, and view of life - in this research. It seems plausible that women with liberal family values perceive fewer benefits from interaction with children and the parental role than women with traditional values, and the former may also rate the opportunity costs of children higher (White and Kim 1987). Thus, we assume that modern family values discouraged women from having a third child. Religiousness, on the other hand, has traditionally been used as a predictor of childbearing behavior, and its positive influence on fertility has emerged in numerous studies (e.g., Hoem 1993; Van den Akker et al. 1993). In contrast, as far as we know, an individual's view of life has not been used in earlier fertility research. We suppose, however, that the intention to have more than two children may be associated with a positive attitude on life.

The variable reflecting family values was based on an exploratory factor analysis of eight items measuring attitudes towards children and family. The final scale consisted of four items assessing the acceptability of abortion, cohabitation, divorce, and single motherhood (the Cronbach's alpha of the scale was 0.652). A scale measuring religiousness consisted of two items: "Excluding weddings, funerals, christenings and confirmations, how often do you attend church events?" and "Regardless of whether or not you go to church, would you consider yourself religious ... opposed to religion?" Finally, a scale reflecting a view of life was based on five items: "It is very difficult to know who to trust these days", "Despite all that is said, things are getting worse for the vast majority of people", "The future is so uncertain that it's best to live one day at a time", "It's futile for those in authority to complain because they are not in the least bit interested in the real problems facing ordinary people", and "It is not fair to bring children into the world with a future such as it is at the moment". The Cronbach's alpha of the scale was 0.610 . 
The three value variables were constructed from the items as follows. All items were first standardized (by subtracting the mean and dividing by the standard deviation) so that each item got an equal weight in determining the overall scale score. After that, arithmetic means of the standardized scores of the items of each variable were calculated. In the end, these three averages were converted to a new metric, ranging from 0 to 1 , and divided into three categories. The first categories represent the scores $0-0.32$ on the scale (i.e., modern family values, secularity, and pessimistic view of life), the second categories represent the scores $0.33-0.66$, and the third categories represent the scores $0.67-1$ (i.e., traditional family values, deep religiousness, and optimistic view of life).

The distributions of all the explanatory variables are presented in Table 1. The righthand column of the table reports the proportion of respondents who desired to have at least three children. 
Table 1. The percentage distributions of the principal study variables, and the proportion of respondents who desired to have at least three children (\%). Finnish married and cohabiting women with two children.

\begin{tabular}{|c|c|c|c|c|}
\hline & & $\mathbf{N}$ & $\%$ & $\begin{array}{c}\text { Desire 3+ } \\
\text { children, \% }\end{array}$ \\
\hline Age group & $\begin{array}{l}22-29 \text { years } \\
30-34 \text { years } \\
35-39 \text { years }\end{array}$ & $\begin{array}{l}165 \\
235 \\
236\end{array}$ & $\begin{array}{l}26 \\
37 \\
37\end{array}$ & $\begin{array}{l}59 \\
46 \\
41\end{array}$ \\
\hline $\begin{array}{l}\text { Time after the } \\
\text { second birth }\end{array}$ & $\begin{array}{l}0-2 \text { years } \\
3-5 \text { years } \\
6-8 \text { years } \\
9 \text { years or more }\end{array}$ & $\begin{array}{l}240 \\
166 \\
115 \\
115\end{array}$ & $\begin{array}{l}38 \\
26 \\
18 \\
18\end{array}$ & $\begin{array}{l}58 \\
48 \\
39 \\
32\end{array}$ \\
\hline $\begin{array}{l}\text { Educational } \\
\text { attainment }\end{array}$ & $\begin{array}{l}\text { Basic } \\
\text { Secondary } \\
\text { Tertiary }\end{array}$ & $\begin{array}{l}112 \\
424 \\
100\end{array}$ & $\begin{array}{l}18 \\
67 \\
16\end{array}$ & $\begin{array}{l}43 \\
47 \\
55\end{array}$ \\
\hline $\begin{array}{l}\text { Number of } \\
\text { siblings }\end{array}$ & $\begin{array}{l}\text { None } \\
\text { One } \\
\text { Two or more }\end{array}$ & $\begin{array}{r}57 \\
103 \\
476\end{array}$ & $\begin{array}{r}9 \\
16 \\
75\end{array}$ & $\begin{array}{l}37 \\
47 \\
50\end{array}$ \\
\hline Marital status & $\begin{array}{l}\text { Married } \\
\text { Cohabited }\end{array}$ & $\begin{array}{r}583 \\
53\end{array}$ & $\begin{array}{r}92 \\
8\end{array}$ & $\begin{array}{l}47 \\
57\end{array}$ \\
\hline Sex of children & $\begin{array}{l}\text { Girl and boy } \\
\text { Two girls } \\
\text { Two boys }\end{array}$ & $\begin{array}{l}315 \\
161 \\
160\end{array}$ & $\begin{array}{l}50 \\
25 \\
25\end{array}$ & $\begin{array}{l}47 \\
52 \\
44\end{array}$ \\
\hline Shared children & $\begin{array}{l}\text { Yes } \\
\text { No }\end{array}$ & $\begin{array}{r}617 \\
19\end{array}$ & $\begin{array}{r}97 \\
3\end{array}$ & $\begin{array}{l}47 \\
58\end{array}$ \\
\hline $\begin{array}{l}\text { Spousal } \\
\text { relationship }\end{array}$ & $\begin{array}{l}\text { Good } \\
\text { Dissatisfactory }\end{array}$ & $\begin{array}{l}481 \\
155\end{array}$ & $\begin{array}{l}76 \\
24\end{array}$ & $\begin{array}{l}49 \\
45\end{array}$ \\
\hline $\begin{array}{l}\text { Financial } \\
\text { situation }\end{array}$ & $\begin{array}{l}\text { Good } \\
\text { Average } \\
\text { Dissatisfactory }\end{array}$ & $\begin{array}{r}187 \\
392 \\
57\end{array}$ & $\begin{array}{r}29 \\
62 \\
9\end{array}$ & $\begin{array}{l}48 \\
47 \\
53\end{array}$ \\
\hline $\begin{array}{l}\text { Opinion about } \\
\text { family benefits }\end{array}$ & $\begin{array}{l}\text { Sufficient } \\
\text { Insufficient }\end{array}$ & $\begin{array}{l}270 \\
366\end{array}$ & $\begin{array}{l}42 \\
58\end{array}$ & $\begin{array}{l}47 \\
49\end{array}$ \\
\hline $\begin{array}{l}\text { Problems with } \\
\text { day-care }\end{array}$ & $\begin{array}{l}\text { No } \\
\text { At least some }\end{array}$ & $\begin{array}{l}400 \\
236\end{array}$ & $\begin{array}{l}63 \\
37\end{array}$ & $\begin{array}{l}47 \\
49\end{array}$ \\
\hline Role orientation & $\begin{array}{l}\text { Work } \\
\text { Home }\end{array}$ & $\begin{array}{l}521 \\
115\end{array}$ & $\begin{array}{l}82 \\
18\end{array}$ & $\begin{array}{l}47 \\
51\end{array}$ \\
\hline Meaning of work & $\begin{array}{l}\text { Instrumental } \\
\text { Content of work }\end{array}$ & $\begin{array}{l}255 \\
381\end{array}$ & $\begin{array}{l}40 \\
60\end{array}$ & $\begin{array}{l}41 \\
52\end{array}$ \\
\hline Family values & $\begin{array}{l}\text { Modern } \\
\text { Average } \\
\text { Traditional }\end{array}$ & $\begin{array}{r}479 \\
123 \\
34\end{array}$ & $\begin{array}{r}75 \\
19 \\
5\end{array}$ & $\begin{array}{l}44 \\
58 \\
69\end{array}$ \\
\hline Religiousness & $\begin{array}{l}\text { Secular } \\
\text { Average } \\
\text { Religious }\end{array}$ & $\begin{array}{r}144 \\
426 \\
66\end{array}$ & $\begin{array}{l}23 \\
67 \\
10\end{array}$ & $\begin{array}{l}42 \\
47 \\
67\end{array}$ \\
\hline View of life & $\begin{array}{l}\text { Pessimistic } \\
\text { Average } \\
\text { Optimistic }\end{array}$ & $\begin{array}{r}97 \\
384 \\
155\end{array}$ & $\begin{array}{l}15 \\
60 \\
24\end{array}$ & $\begin{array}{l}48 \\
48 \\
48\end{array}$ \\
\hline ALL WOMEN & & 636 & 100 & 48 \\
\hline
\end{tabular}




\section{Methods}

Our analysis was based on the assumption that uncertainty is a transitional phase between the decision to continue or stop childbearing, and therefore we considered three-category responses (yes, uncertain and no) as an ordinal measure of the intention for an additional birth.

We used binominal logistic regression as the principal analytical method. We did modeling in three stages. In the first stage our focus was on the probability of giving 'yes' or 'unsure' responses versus the probability of giving a 'no' response to the intention question. In this stage we studied the determinants to continue childbearing (in general). The purpose of the second stage was to find out what kind of factors predict the certainty of the intention among women who answered 'yes' or 'unsure'. In this second stage we contrasted the 'yes' responses with the 'unsure' responses. In the third stage our interest was in the certainty of the decision to stop childbearing: we contrasted 'could change mind' responses with 'could not change mind' responses among women who intended not to have a third child.

All the explanatory analyses were made separately for all women who met the selection criteria presented above $(\mathrm{n}=636)$, and additionally for the women who desired to have three or more children $(n=302)^{2}$. We want to make clear that these groups differ from each other. Because intended childbearing is primarily grounded in family-size preferences, factors that predict desired family size also get strong emphasis as determinants of childbearing intentions among all women at a given parity. However, if we restrict our attention exclusively to women who wish to have more children than they currently have, the focus of the study becomes easier to identify, as we are examining the factors that determine women's perceived capability to realize their fertility desires.

When modeling, we began by studying the bivariate associations between the explanatory variables and each of the dependent variables, controlled for woman's age and age of the second child. The results of these analyses are shown in the first column of Tables 5, 6, and 7 for all women, and in the third column of the same tables for women who desired to have three or more children. We do not show the "raw-effects" of variables, i.e., effects occurring when none of the other factors are controlled, because we see that variables' own influence emerges better when the reproductive life stage of respondents has been controlled.

\footnotetext{
2 The desired family size was determined with the question 'If you could choose, how many children would you have?' If the answer to this question was given as a range, for example 2 or 3 children, we used the lower alternative. We omitted nine cases in which the question concerning desired family size was not answered from the analyses restricted to women desiring three or more children.
} 
The second and fourth columns of Tables 5, 6, and 7 present the results of multiple logistic regression analyses in which all the explanatory variables which had a pvalue $<0.25$ in the bivariate analyses were included. Hosmer and Lemeshow (1989, p. 86) suggest using this criterion of variable selection in situations where the number in each outcome group relative to the total number of candidate variables is relatively small.

We performed a global test for non-linearity for the effects of respondent's age and age of the second child on intention status. It was observed that the effect of respondent's age on intention was not linear (this was the case especially in analyses focusing on the certainty of the third-birth intention). To improve the model fit, we included respondent's age in a discrete form. Because the focus of our interest was in the effects of the covariates on childbearing intention among different subsamples of respondents, we wanted to keep the models themselves relatively simple. The Hosmer-Lemeshow $\chi^{2}$ goodness-of-fit statistics reveal, in fact, that the model fit is adequately good in all analyses. Hence, no complex variables, like interactions between the covariates, were necessary to model the data.

All other explanatory variables except the age of the second child were used in the form of indicator variables. Thus the odds ratio of intention for each category versus the reference category is received from the estimated logit coefficients (b) by the transformation $\mathrm{e}^{\mathrm{b}}$.

A common practice in previous studies about birth intentions has been to exclude pregnant respondents from the analysis. However, we estimated separate models that ignored the women who were pregnant, and found results very similar to those reported later in this paper. Therefore, we decided to include pregnant respondents among the women who intended to have a third child. 


\section{Results}

\section{Descriptive analysis}

As Table 1 shows, almost one half of the two-child mothers in our sample wished to have three or more children. However, only 19 percent of the respondents intended to have a third child, while 30 percent were unsure about their intentions. The remaining 51 percent of respondents said that they would not have any children in the future (Table 2).

Table 2. Birth intentions by the desired number of children, married and cohabiting Finnish women with two children.

\begin{tabular}{lccccc}
\hline & $\mathbf{N}$ & $\begin{array}{c}\text { Intends to } \\
\text { have a child }\end{array}$ & Uncertain & $\begin{array}{c}\text { Intends not to } \\
\text { have a child }\end{array}$ & Total \\
\hline All women & 636 & 19 & 30 & 51 & $100 \%$ \\
$\begin{array}{l}\text { Desired family } \\
\text { size at least 3 children }\end{array}$ & 302 & 38 & 36 & 26 & $100 \%$ \\
$\begin{array}{l}\text { Desired family } \\
\text { size 2 children or less }\end{array}$ & 325 & 2 & 24 & 74 & $100 \%$ \\
\hline
\end{tabular}

Preferred number of children seems to be a very strong determinant of birth intentions, since merely those women whose family size desires had not yet been realized intended to have more children. Only two percent of the respondents who desired to have two children intended to have a third child. In the case of women whose desired number of children was three or more, 38 percent said that they will go on and have a third birth, while 36 percent were uncertain about their intentions. However, a quarter of the two-child mothers desiring three or more children said that they would stop childbearing at the current parity.

In the explanatory analysis we focus our interest on the childbearing intentions of the 22-39-year-old women, who had two children of their own at the time of the survey. It must be noted, however, that a notable proportion of the women especially in older age groups - who had intended to have a third child, had already implemented their plans before the data were collected. This is demonstrated in Table 3, in which we also included women who already had three or more children. 
Table 3. Number of children and childbearing intention (\%) by respondent's age, age of second child, and education by age among married and cohabiting Finnish women with at least two children.

\begin{tabular}{|c|c|c|c|c|c|c|c|}
\hline & & $\mathbf{N}$ & $\begin{array}{l}3 \text { children } \\
\text { or more }\end{array}$ & $\begin{array}{l}2 \text { children } \\
\text { Intends to } \\
\text { have a third } \\
\text { child }\end{array}$ & $\begin{array}{l}2 \text { children } \\
\text { Unsure } \\
\text { about having } \\
\text { a third child }\end{array}$ & $\begin{array}{l}2 \text { children } \\
\text { Intends not } \\
\text { to have a } \\
\text { third child }\end{array}$ & Total \\
\hline \multirow{3}{*}{$\begin{array}{l}\text { Respondent's } \\
\text { age }\end{array}$} & $22-29$ years & 200 & 18 & 30 & 32 & 21 & $100 \%$ \\
\hline & 30-34 years & 340 & 31 & 14 & 24 & 30 & $100 \%$ \\
\hline & 35-39 years & 362 & 35 & 4 & 12 & 49 & $100 \%$ \\
\hline \multirow{4}{*}{$\begin{array}{l}\text { Age of } \\
\text { second child }\end{array}$} & $0-2$ years & 248 & 3 & 29 & 36 & 33 & $100 \%$ \\
\hline & $3-5$ years & 221 & 25 & 14 & 24 & 37 & $100 \%$ \\
\hline & $6-8$ years & 197 & 42 & 7 & 17 & 35 & $100 \%$ \\
\hline & 9 years + & 236 & 51 & 4 & 7 & 38 & $100 \%$ \\
\hline \multicolumn{8}{|c|}{ Education by age } \\
\hline \multirow[t]{3}{*}{$22-29$ years } & Basic & 37 & 32 & 27 & 16 & 24 & $100 \%$ \\
\hline & Secondary & 150 & 15 & 30 & 34 & 21 & $100 \%$ \\
\hline & Tertiary & 13 & 0 & 31 & 54 & 15 & $100 \%$ \\
\hline \multirow[t]{3}{*}{ 30-34 years } & Basic & 63 & 40 & 11 & 22 & 27 & $100 \%$ \\
\hline & Secondary & 218 & 29 & 12 & 26 & 34 & $100 \%$ \\
\hline & Tertiary & 59 & 29 & 27 & 22 & 22 & $100 \%$ \\
\hline \multirow[t]{3}{*}{$35-39$ years } & Basic & 83 & 41 & 5 & 10 & 45 & $100 \%$ \\
\hline & Secondary & 213 & 33 & 3 & 13 & 51 & $100 \%$ \\
\hline & Tertiary & 66 & 32 & 6 & 15 & 47 & $100 \%$ \\
\hline All women & & 902 & 30 & 14 & 21 & 36 & $100 \%$ \\
\hline
\end{tabular}

The proportion of women intending to have a third child decreased sharply with age. This was, at least partly because among the older women, many respondents who had wished to have three children had already moved to parity three. The same could be seen when the age of the second child was looked at: the older the child, the smaller the proportion of women who intended to have a third birth, but the larger the proportion of those women who already had at least three children. Therefore, we see woman's age and age of the second child as control variables rather than real explanatory variables in the explanatory analysis.

We consider educational attainment as a strategy variable, because we think that women with different educational levels have different childbearing strategies. Highly educated women generally start childbearing in a later phase of their reproductive life than women with a shorter education. Therefore, compared to women with basic and secondary education, those with a tertiary education are 
behind in their childbearing. (For a detailed analysis of the effects of age and education on fertility, see Hoem 1996).

When inspecting women's third-birth intentions by education and age in the three bottom panels of Table 3, we see that highly educated respondents were somewhat more likely to have a third birth than the other respondents within all age groups. However, among women of different ages, it was the respondents with basic education who had progressed to parity three most often. Thus, when using crosssectional data, the associations between educational attainment and childbearing intentions are difficult to interpret, because they can be a result of different timing of childbearing in different educational groups.

\section{Explanatory analysis}

Intention to continue childbearing or to stop at parity two. In the first stage of the explanatory analysis we examined the determinants of giving 'yes' or 'unsure' responses versus a ' $n o$ ' response to the intention question. The results are presented in Table 4, where an estimate larger than 1.00 means a greater likelihood of choosing 'yes' or 'unsure' responses over 'no' (i.e., to consider additional childbearing as possible). 
Table 4. Logistic regression models for the intention to have another child (intends or uncertain vs. intends not): Finnish married or cohabiting women with two children. The figures are odds ratios.

\begin{tabular}{|c|c|c|c|c|c|}
\hline \multirow[t]{2}{*}{ Variable } & \multirow[t]{2}{*}{ Category } & \multicolumn{2}{|c|}{ ALL WOMEN (n=636) } & \multicolumn{2}{|c|}{ DESIRED 3+ $(n=302)$} \\
\hline & & $\begin{array}{l}\text { Age and age } \\
\text { of second child } \\
\text { controlled for }\end{array}$ & $\begin{array}{l}\text { Net } \\
\text { effects }\end{array}$ & $\begin{array}{l}\text { Age and age } \\
\text { of second child } \\
\text { controlled for }\end{array}$ & $\begin{array}{l}\text { Net } \\
\text { effects }\end{array}$ \\
\hline Age & $\begin{array}{l}22-29 \\
30-34 \\
35-39\end{array}$ & & $\begin{array}{l}1 \\
0.47^{* *} \\
0.14^{* *}\end{array}$ & & $\begin{array}{l}1 \\
0.22^{* *} \\
0.03^{* *}\end{array}$ \\
\hline Time after $2^{\text {nd }}$ birth & & & $0.99 * *$ & & 1.00 \\
\hline $\begin{array}{l}\text { Educational } \\
\text { attainment }\end{array}$ & $\begin{array}{l}\text { Basic } \\
\text { Secondary } \\
\text { Tertiary }\end{array}$ & $\begin{array}{l}1 \\
1.02 \\
1.50\end{array}$ & & $\begin{array}{l}1 \\
1.05 \\
1.99\end{array}$ & \\
\hline $\begin{array}{l}\text { Number of } \\
\text { siblings }\end{array}$ & $\begin{array}{l}\text { None } \\
\text { One } \\
\text { Two or more }\end{array}$ & $\begin{array}{l}1 \\
1.82 \\
1.69\end{array}$ & $\begin{array}{l}1 \\
1.92+ \\
1.72\end{array}$ & $\begin{array}{l}1 \\
1.61 \\
0.85\end{array}$ & \\
\hline Marital status & $\begin{array}{l}\text { Married } \\
\text { Cohabited }\end{array}$ & $\begin{array}{l}1 \\
0.94\end{array}$ & & $\begin{array}{l}1 \\
1.81\end{array}$ & \\
\hline Sex of children & $\begin{array}{l}\text { Girl and boy } \\
\text { Two girls } \\
\text { Two boys }\end{array}$ & $\begin{array}{l}1 \\
1.49+ \\
1.28\end{array}$ & $\begin{array}{l}1 \\
1.69^{*} \\
1.45^{+}\end{array}$ & $\begin{array}{l}1 \\
0.80 \\
0.87\end{array}$ & \\
\hline $\begin{array}{l}\text { Shared } \\
\text { children }\end{array}$ & $\begin{array}{l}\text { Yes } \\
\text { No }\end{array}$ & $\begin{array}{l}1 \\
3.79^{*}\end{array}$ & $\begin{array}{l}1 \\
5.00^{* *}\end{array}$ & - & \\
\hline $\begin{array}{l}\text { Spousal } \\
\text { relationship }\end{array}$ & $\begin{array}{l}\text { Good } \\
\text { Dissatisfactory }\end{array}$ & $\begin{array}{l}1 \\
0.51^{*}\end{array}$ & $\begin{array}{l}1 \\
0.59 *\end{array}$ & 1 & $\begin{array}{l}1 \\
0.33^{* *}\end{array}$ \\
\hline $\begin{array}{l}\text { Financial } \\
\text { situation }\end{array}$ & $\begin{array}{l}\text { Good } \\
\text { Average } \\
\text { Dissatisfactory }\end{array}$ & $\begin{array}{l}1 \\
0.86 \\
0.52^{*}\end{array}$ & $\begin{array}{l}1 \\
1.06 \\
0.66\end{array}$ & $\begin{array}{l}1 \\
0.77 \\
0.25^{\star}\end{array}$ & $\begin{array}{l}1 \\
1.13 \\
0.42\end{array}$ \\
\hline $\begin{array}{l}\text { Opinion about } \\
\text { family benefits }\end{array}$ & $\begin{array}{l}\text { Sufficient } \\
\text { Insufficient }\end{array}$ & $\begin{array}{l}1 \\
0.82\end{array}$ & & $\begin{array}{l}1 \\
0.69\end{array}$ & $\begin{array}{l}1 \\
0.78\end{array}$ \\
\hline $\begin{array}{l}\text { Problems with } \\
\text { day-care }\end{array}$ & $\begin{array}{l}\text { No } \\
\text { At least some }\end{array}$ & $\begin{array}{l}1 \\
1.14\end{array}$ & & $\begin{array}{l}1 \\
1.33\end{array}$ & \\
\hline $\begin{array}{l}\text { Meaning of } \\
\text { work }\end{array}$ & $\begin{array}{l}\text { Instrumental } \\
\text { Content of work }\end{array}$ & $\begin{array}{l}1 \\
1.60^{* *}\end{array}$ & $\begin{array}{l}1 \\
1.49^{*}\end{array}$ & $1.77+$ & $\begin{array}{l}1 \\
1.67\end{array}$ \\
\hline Role orientation & $\begin{array}{l}\text { Work } \\
\text { Home }\end{array}$ & $\begin{array}{l}1 \\
1.03\end{array}$ & & $\begin{array}{l}1 \\
0.97\end{array}$ & \\
\hline Family values & $\begin{array}{l}\text { Modern } \\
\text { Average } \\
\text { Traditional }\end{array}$ & $\begin{array}{l}1 \\
1.78^{* *} \\
2.94^{* *}\end{array}$ & $\begin{array}{l}1 \\
1.71^{\star} \\
2.40^{+}\end{array}$ & $\begin{array}{l}1 \\
1.36 \\
3.98^{*}\end{array}$ & $\begin{array}{l}1 \\
1.11 \\
2.82\end{array}$ \\
\hline Religiousness & $\begin{array}{l}\text { Secular } \\
\text { Average } \\
\text { Religious }\end{array}$ & $\begin{array}{l}1 \\
1.22 \\
2.30^{*}\end{array}$ & $\begin{array}{l}1 \\
1.09 \\
1.42\end{array}$ & $\begin{array}{l}1 \\
1.01 \\
1.31\end{array}$ & \\
\hline View of life & $\begin{array}{l}\text { Pessimistic } \\
\text { Average } \\
\text { Optimistic }\end{array}$ & $\begin{array}{l}1 \\
1.29 \\
1.74+\end{array}$ & $\begin{array}{l}1 \\
1.10 \\
1.47\end{array}$ & $\begin{array}{l}1 \\
1.54 \\
2.56+\end{array}$ & $\begin{array}{l}1 \\
0.97 \\
1.62\end{array}$ \\
\hline $\begin{array}{l}\text { Hosmer-Lemeshow } \chi^{2} \\
\text { d.f. } \\
p\end{array}$ & & & $\begin{array}{l}9.9 \\
8 \\
.272\end{array}$ & & $\begin{array}{l}3.0 \\
4 \\
.555\end{array}$ \\
\hline
\end{tabular}

** = Statistically significant at the 1 percent level, ${ }^{*}=5$ percent level, $+=10$ percent level.

For each variable, risks and their significance are given relative to the reference category (the first category).

Note: The odds of the 'shared children' variable could not be calculated for women who desired to have three or more children. This was because all the women who had no children with the current partner and who desired to have at least three children considered future childbearing a possibility. 
Beginning with the models concerning all women, we see numerous results that are consistent with our hypotheses and previous results. When examining the statistical significance of the coefficients, we find that several factors reflecting family composition and family relations were significantly associated with the intention to stop or continue childbearing after two children. The odds of the women with two boys and two girls to consider further childbearing as possible were, respectively, 45 and 70 percent larger than the odds of the women with a girl and a boy, other things being equal. The corresponding odds of the respondents whose children were born before the current union were five times higher compared to women whose spouse was the father of the existing children. And the estimated odds of women living in a dissatisfying relationship to continue childbearing were only 0.6 times that of women who were satisfied with their partner, controlled for other things. While no effects were found for union status, having no siblings increased the probability of the decision to stop childbearing at the second parity, but this result was only marginally significant.

Contrary to our expectations, respondents who appreciated the content of the work considered additional childbearing as possible significantly more often than respondents who said that the most important thing with respect to work is a good salary or steadiness of the employment. Instead, unsatisfying economic situation decreased respondents' odds of continuing childbearing as expected, but this result was not significant after the other variables in the model were controlled. Other things being equal, the odds of women with traditional family values to consider future childbearing as possible were over two times higher compared to women with modern family values.

The fourth column of Table 4 shows covariates' net effects for women who desired to have three or more children. While spousal relationship still remained statistically highly significant determinant of the intention status - revealing that dissatisfaction with a partner made women stop childbearing at a lower parity than desired-some other familial and attitudinal determinants, which were significant antecedents of the intention among all women, had little independent impact in this analysis.

As we can see from the last column of Table 1, several familial and attitudinal variables were clearly associated with the desired family size. In turn, the number of children desired was a strong determinant of childbearing intention (see Table 2). Because the family size preferences were not taken into account in the analysis discussed above, the factors determining desired family size got a strong emphasis as determinants of childbearing intentions among all women. However, after the desired family size was controlled, these factors had little independent influence on birth intentions. 
Even though we think it is difficult to draw conclusions about the independent effect of respondent's age on her birth intention when using cross-sectional data, we think that the interpretation of this relationship becomes less problematic when the desired number of children has been controlled. We obtained strong evidence that an older age made respondents give up their desires to have three children, and made them stop childbearing at the second parity.

Certainty of the intention to have a third birth. Next we investigate the certainty of third-birth plans by estimating the probability of giving a 'yes' response versus an 'unsure' response to the intention question. These results are displayed in Table 5, where an estimate larger than 1.00 means a greater likelihood of choosing 'yes' over 'unsure' (i.e., to consider additional childbearing as certain). 
Table 5. Logistic regression models for the certainty of the intention to have another child (intends vs. uncertain): Finnish married or cohabiting women with two children. The figures are odds ratios.

\begin{tabular}{|c|c|c|c|c|c|}
\hline \multirow[t]{2}{*}{ Variable } & \multirow[t]{2}{*}{ Category } & \multicolumn{2}{|c|}{ ALL WOMEN $(n=315)$} & \multicolumn{2}{|c|}{ DESIRED 3+ $(n=224)$} \\
\hline & & $\begin{array}{l}\text { Age and age } \\
\text { of second child } \\
\text { controlled for }\end{array}$ & $\begin{array}{l}\text { Net } \\
\text { effects }\end{array}$ & $\begin{array}{l}\text { Age and age } \\
\text { of second child } \\
\text { controlled for }\end{array}$ & $\begin{array}{l}\text { Net } \\
\text { effects }\end{array}$ \\
\hline Age & $\begin{array}{l}22-29 \\
30-34 \\
35-39\end{array}$ & & $\begin{array}{l}1 \\
0.58+ \\
0.27^{* *}\end{array}$ & & $\begin{array}{l}1 \\
0.51+ \\
0.25^{\star *}\end{array}$ \\
\hline Time after $2^{\text {nd }}$ birth & & & 1.00 & & 1.00 \\
\hline $\begin{array}{l}\text { Educational } \\
\text { attainment }\end{array}$ & $\begin{array}{l}\text { Basic } \\
\text { Secondary } \\
\text { Tertiary }\end{array}$ & $\begin{array}{l}1 \\
0.67 \\
1.13\end{array}$ & $\begin{array}{l}1 \\
0.64 \\
1.06\end{array}$ & $\begin{array}{l}1 \\
0.46+ \\
0.67\end{array}$ & $\begin{array}{l}1 \\
0.40+ \\
0.50\end{array}$ \\
\hline $\begin{array}{l}\text { Number of } \\
\text { siblings }\end{array}$ & $\begin{array}{l}\text { None } \\
\text { One } \\
\text { Two or more }\end{array}$ & $\begin{array}{l}1 \\
1.34 \\
1.08\end{array}$ & & $\begin{array}{l}1 \\
0.93 \\
0.95\end{array}$ & \\
\hline Marital status & $\begin{array}{l}\text { Married } \\
\text { Cohabited }\end{array}$ & $\begin{array}{l}1 \\
0.61\end{array}$ & $\begin{array}{l}1 \\
0.38+\end{array}$ & $\begin{array}{l}1 \\
0.42+\end{array}$ & $\begin{array}{l}1 \\
0.27^{*}\end{array}$ \\
\hline Sex of children & $\begin{array}{l}\text { Girl and boy } \\
\text { Two girls } \\
\text { Two boys }\end{array}$ & $\begin{array}{l}1 \\
1.04 \\
1.10\end{array}$ & & $\begin{array}{l}1 \\
1.17 \\
1.46\end{array}$ & \\
\hline $\begin{array}{l}\text { Shared } \\
\text { children }\end{array}$ & $\begin{array}{l}\text { Yes } \\
\text { No }\end{array}$ & $\begin{array}{l}1 \\
4.91^{*}\end{array}$ & $\begin{array}{l}1 \\
9.67^{* *}\end{array}$ & $\begin{array}{l}1 \\
2.11\end{array}$ & $\begin{array}{l}1 \\
5.21^{*}\end{array}$ \\
\hline $\begin{array}{l}\text { Spousal } \\
\text { relationship }\end{array}$ & $\begin{array}{l}\text { Good } \\
\text { Dissatisfactory }\end{array}$ & $\begin{array}{l}1 \\
0.78\end{array}$ & & $\begin{array}{l}1 \\
1.05\end{array}$ & \\
\hline $\begin{array}{l}\text { Financial } \\
\text { situation }\end{array}$ & $\begin{array}{l}\text { Good } \\
\text { Average } \\
\text { Dissatisfactory }\end{array}$ & $\begin{array}{l}1 \\
0.74 \\
0.68\end{array}$ & & $\begin{array}{l}1 \\
0.76 \\
0.74\end{array}$ & \\
\hline $\begin{array}{l}\text { Opinion about } \\
\text { family benefits }\end{array}$ & $\begin{array}{l}\text { Sufficient } \\
\text { Insufficient }\end{array}$ & $\begin{array}{l}1 \\
0.58^{*}\end{array}$ & $\begin{array}{l}1 \\
0.52^{* *}\end{array}$ & $\begin{array}{l}1 \\
0.60+\end{array}$ & $\begin{array}{l}1 \\
0.55^{\star}\end{array}$ \\
\hline $\begin{array}{l}\text { Problems with } \\
\text { day-care }\end{array}$ & $\begin{array}{l}\text { No } \\
\text { At least some }\end{array}$ & $\begin{array}{l}1 \\
0.90\end{array}$ & & $\begin{array}{l}1 \\
0.93\end{array}$ & \\
\hline $\begin{array}{l}\text { Meaning of } \\
\text { work }\end{array}$ & $\begin{array}{l}\text { Instrumental } \\
\text { Content of work }\end{array}$ & 1.01 & & $\begin{array}{l}1 \\
0.78\end{array}$ & \\
\hline Role orientation & $\begin{array}{l}\text { Work } \\
\text { Home }\end{array}$ & $\begin{array}{l}1 \\
0.99\end{array}$ & & $\begin{array}{l}1 \\
0.88\end{array}$ & \\
\hline Family values & $\begin{array}{l}\text { Modern } \\
\text { Average } \\
\text { Traditional }\end{array}$ & $\begin{array}{l}1 \\
1.28 \\
2.09\end{array}$ & $\begin{array}{l}1 \\
1.01 \\
0.82\end{array}$ & $\begin{array}{l}1 \\
1.18 \\
1.29\end{array}$ & \\
\hline Religiousness & $\begin{array}{l}\text { Secular } \\
\text { Average } \\
\text { Religious }\end{array}$ & $\begin{array}{l}1 \\
0.92 \\
2.73^{*}\end{array}$ & $\begin{array}{l}1 \\
1.03 \\
3.33^{*}\end{array}$ & $\begin{array}{l}1 \\
0.61 \\
1.58\end{array}$ & $\begin{array}{l}1 \\
0.66 \\
1.56\end{array}$ \\
\hline View of life & $\begin{array}{l}\text { Pessimistic } \\
\text { Average } \\
\text { Optimistic }\end{array}$ & $\begin{array}{l}1 \\
1.58 \\
1.86\end{array}$ & & $\begin{array}{l}1 \\
1.89 \\
2.31+\end{array}$ & $\begin{array}{l}1 \\
1.73 \\
2.19\end{array}$ \\
\hline $\begin{array}{l}\text { Hosmer-Lemeshow } \chi^{2} \\
\text { d.f. } \\
\text { p }\end{array}$ & & & $\begin{array}{l}6.0 \\
8 \\
.643\end{array}$ & & $\begin{array}{l}7.0 \\
8 \\
.536\end{array}$ \\
\hline
\end{tabular}

${ }^{* *}=$ Statistically significant at the 1 percent level, ${ }^{*}=5$ percent level, $+=10$ percent level. For each variable, risks and their significance are given relative to the reference category (the first category). 
Inspecting all women with two children, married respondents were more certain about their intention to continue childbearing than were cohabiting respondents, but this result was only marginally significant. In addition, the odds that respondents whose existing children were born to a previous partner considered future childbearing as certain were almost ten times higher compared to the odds among women whose partner was the father of the existing children, other things being equal.

We also found that satisfaction with family benefits was strongly associated with the certainty of third-child plans: the odds of the respondents who found the level of public aid insufficient were only half of those of women who found the level of these benefits sufficient. Religiousness was an important predictor of intention status as well, since religious respondents' odds of being certain about their intentions were about three times higher compared to women who were secular or somewhat religious.

The results reported in the fourth column of Table 5 generally follow a similar pattern to the one reported above. Accordingly, among respondents whose desired family-size had not yet been realized, substantial differences in the certainty of intentions were observed depending on marital status, opinion about the sufficiency of family benefits, and the 'shared children' -variable. Additionally, educational attainment appeared to have some independent effect in this analysis; the results reveal that respondents with a secondary-level education were less assured about their intention to have a third child than were respondents with a basic-level education. Also, older age made women hesitate in their intention to have a third birth.

Certainty of the decision to stop childbearing at parity two. All women who gave the 'no' response to the intention question were asked: 'Could any changes in society or in your private life make you change your mind and make you decide to have another child?' At parity two, as many as 37 percent of the respondents intending to stop childbearing said that they could have a third child if some changes in their circumstances occurred. We modeled the probability of this answer by binominal logistic regression. Parameter estimates are presented in Table 6, where an estimate larger than 1.00 means a greater likelihood of choosing a 'could change mind' response over 'could not'. 
Table 6. Logistic regression models for the certainty of the intention not to have any more children (could change mind vs. couldn't change mind about the decision to stop childbearing): Finnish married or cohabiting women with two children. The figures are odds ratios.

\begin{tabular}{|c|c|c|c|c|c|}
\hline \multirow[t]{2}{*}{ Variable } & \multirow[t]{2}{*}{ Category } & \multicolumn{2}{|c|}{ ALL WOMEN $(n=321)$} & \multicolumn{2}{|c|}{ DESIRED 3+ (n=78) } \\
\hline & & $\begin{array}{l}\text { Age and age } \\
\text { of second child } \\
\text { controlled for }\end{array}$ & $\begin{array}{l}\text { Net } \\
\text { effects }\end{array}$ & $\begin{array}{l}\text { Age and age } \\
\text { of second child } \\
\text { controlled for }\end{array}$ & $\begin{array}{l}\text { Net } \\
\text { effects }\end{array}$ \\
\hline Time after $2^{\text {nd }}$ birth & $\begin{array}{l}22-29 \\
30-34 \\
35-39\end{array}$ & & $\begin{array}{l}1 \\
1.42 \\
0.82 \\
1.00\end{array}$ & & $\begin{array}{l}1 \\
1.32 \\
1.36 \\
1.00\end{array}$ \\
\hline Educational & Basic & 1 & & 1 & \\
\hline attainment & $\begin{array}{l}\text { Secondary } \\
\text { Tertiary }\end{array}$ & $\begin{array}{l}1.16 \\
0.95\end{array}$ & & $\begin{array}{l}1.62 \\
1.45\end{array}$ & \\
\hline $\begin{array}{l}\text { Number of } \\
\text { siblings }\end{array}$ & $\begin{array}{l}\text { None } \\
\text { One } \\
\text { Two or more }\end{array}$ & $\begin{array}{l}1 \\
1.87 \\
1.64\end{array}$ & & $\begin{array}{l}1 \\
5.59 \\
5.18\end{array}$ & \\
\hline $\begin{array}{l}\text { Marital status } \\
\text { status }\end{array}$ & $\begin{array}{l}\text { Married } \\
\text { Cohabited }\end{array}$ & $\begin{array}{l}1 \\
0.98\end{array}$ & & $\begin{array}{l}1 \\
1.06\end{array}$ & \\
\hline Sex of children & $\begin{array}{l}\text { Girl and boy } \\
\text { Two girls } \\
\text { Two boys }\end{array}$ & $\begin{array}{l}1 \\
1.17 \\
0.98\end{array}$ & & $\begin{array}{l}1 \\
0.60 \\
0.60\end{array}$ & \\
\hline $\begin{array}{l}\text { Shared } \\
\text { children }\end{array}$ & $\begin{array}{l}\text { Yes } \\
\text { No }\end{array}$ & $\begin{array}{l}1 \\
1.06\end{array}$ & & - & \\
\hline $\begin{array}{l}\text { Spousal } \\
\text { relationship }\end{array}$ & $\begin{array}{l}\text { Good } \\
\text { Dissatisfactory }\end{array}$ & $\begin{array}{l}1 \\
1.30\end{array}$ & & $\begin{array}{l}1 \\
1.70\end{array}$ & \\
\hline $\begin{array}{l}\text { Financial } \\
\text { situation }\end{array}$ & $\begin{array}{l}\text { Good } \\
\text { Average } \\
\text { Dissatisfactory }\end{array}$ & $\begin{array}{l}1 \\
1.65+ \\
3.05^{* *}\end{array}$ & $\begin{array}{l}1 \\
1.45 \\
1.92\end{array}$ & $\begin{array}{l}1 \\
1.47 \\
7.99^{*}\end{array}$ & $\begin{array}{l}1 \\
1.08 \\
6.68^{*}\end{array}$ \\
\hline $\begin{array}{l}\text { Opinion about } \\
\text { family benefits }\end{array}$ & $\begin{array}{l}\text { Sufficient } \\
\text { Insufficient }\end{array}$ & $\begin{array}{l}1 \\
2.53^{* *}\end{array}$ & 1 2.15** & $\begin{array}{l}1 \\
1.25\end{array}$ & \\
\hline $\begin{array}{l}\text { Problems with } \\
\text { day-care }\end{array}$ & $\begin{array}{l}\text { No } \\
\text { At least some }\end{array}$ & $\begin{array}{l}1 \\
1.77^{*}\end{array}$ & $\begin{array}{l}1 \\
1.64+\end{array}$ & $\begin{array}{l}1 \\
0.93\end{array}$ & \\
\hline $\begin{array}{l}\text { Meaning of } \\
\text { work }\end{array}$ & $\begin{array}{l}\text { Instrumental } \\
\text { Content of work }\end{array}$ & $\begin{array}{l}1 \\
0.82\end{array}$ & & $\begin{array}{l}1 \\
0.61\end{array}$ & \\
\hline Role orientation & $\begin{array}{l}\text { Work } \\
\text { Home }\end{array}$ & $\begin{array}{l}1 \\
1.01\end{array}$ & & $\begin{array}{l}1 \\
1.13\end{array}$ & \\
\hline Family values & $\begin{array}{l}\text { Modern } \\
\text { Average } \\
\text { Traditional }\end{array}$ & $\begin{array}{l}1 \\
1.56 \\
0.36\end{array}$ & $\begin{array}{l}1 \\
1.76 \\
0.42\end{array}$ & $\begin{array}{l}1 \\
2.14 \\
0.43\end{array}$ & \\
\hline Religiousness & $\begin{array}{l}\text { Secular } \\
\text { Average } \\
\text { Religious }\end{array}$ & $\begin{array}{l}1 \\
0.67 \\
0.43\end{array}$ & $\begin{array}{l}1 \\
0.64 \\
0.54\end{array}$ & $\begin{array}{l}1 \\
0.44 \\
0.11^{*}\end{array}$ & $\begin{array}{l}1 \\
0.43 \\
0.11^{*}\end{array}$ \\
\hline View of life & $\begin{array}{l}\text { Pessimistic } \\
\text { Average } \\
\text { Optimistic }\end{array}$ & $\begin{array}{l}1 \\
0.55+ \\
0.29^{* *}\end{array}$ & $\begin{array}{l}1 \\
0.58 \\
0.32^{* *}\end{array}$ & $\begin{array}{l}1 \\
0.48 \\
0.62\end{array}$ & \\
\hline $\begin{array}{l}\text { Hosmer-Lemeshow } \chi^{2} \\
\text { d.f. } \\
\text { p }\end{array}$ & & & $\begin{array}{l}8.9 \\
8 \\
.352\end{array}$ & & $\begin{array}{l}0.5 \\
3 \\
.912\end{array}$ \\
\hline
\end{tabular}

** $=$ Statistically significant at the 1 percent level, ${ }^{*}=5$ percent level, $+=10$ percent level. For each variable, risks and their significance are given relative to the reference category (the first category).

Note: The odds of the 'shared children' variable could not be calculated for women who desired to have three or more children. This was because none of the women who had no children with the current partner and who desired to have at least three children were going to stop childbearing at the second parity. 
Economic and socio-political factors proved to be significant determinants of the certainty of the decision to stop childbearing at the second parity. Controlled for other variables, respondents who reported problems with their children's day-care arrangements were more likely than respondents without day-care problems to say that they could change their mind and have a third child. Furthermore, the odds of respondents who saw their financial situation as dissatisfactory to reverse their negative intention and have a third birth were three times as great as the odds of women who considered their economic situation satisfactory; however, the statistical significance of this variable diminished after the other variables in the analysis were held constant. Opinion about the sufficiency of family benefits was an important predictor in this analysis as well, since the odds of the women who considered family support insufficient to change their mind and have a third child were over two times higher compared to women who saw the level of family benefits as sufficient, other things being equal.

While no significant effects were found for the familial determinants, a positive view of life showed an independent influence on the certainty of a negative intention. Indeed, the optimistic respondents were more assured than pessimistic ones about their decision to stop childbearing.

Satisfaction with the family's financial situation was a strong determinant of the certainty of the decision to stop childbearing, when only those women who desired to have three or more children were considered: the odds that a respondent could change her mind and have a third child were estimated to be more than six times higher for respondents who were dissatisfied with their financial circumstances compared to those who were satisfied with their family economies. The result indicates that an unfavorable economic situation was seen as an obstacle, which prevented respondents from having the number of children desired.

\section{Discussion and conclusions}

In this paper we have studied the decision to have or not have a third child among Finnish women who already had two children. On the whole, our results indicate that childbearing intentions concerning third births are not fixed, since almost half (altogether 49 per cent) of the respondents in our sample were more or less unsure whether to continue or stop childbearing after the second birth. We also found that a considerable proportion of the two-child mothers who desired to have three or more children hesitated about future childbearing or had decided to stop having children at the current parity.

Our results reveal that personal and interpersonal factors, such as the quality of partnership, family composition characteristics, and family values, were 
independently associated with women's intentions to continue childbearing after two children or to stop at parity two. Several findings are worth mentioning. First, marital dissatisfaction clearly made respondents stop childbearing at the second parity. Conversely, traditional family values were associated with intentions to have a third child. If the respondent did not have shared children with her current partner, she was eager to continue childbearing as well.

Our results also suggest that women with an unbalanced gender composition of children may prefer a subsequent birth of the opposite gender, because they intended to have a third birth more often than did women with one boy and one girl. Moreover, respondents with two girls seemed to be more likely to prefer a boy for the next child than were respondents with two boys to prefer a girl (for corresponding results, see Kartovaara 1999; Hoem 1993). In Scandinavia, where a strong emphasis has traditionally been given to gender equality, this result is surprising, especially as available research from the United States and Canada indicates that further births are not influenced by a preference for one gender over the other (Sloane and Lee 1983; Wu and Wang 1998; Yamaguchi and Ferguson 1995). Another possible interpretation of the result is, however, that parents perceive the upbringing of boys as more demanding, and thus families with two girls are more inclined to have a third child than families with a girl and a boy or two boys.

Among respondents whose family-size preferences had not yet been realized, dissatisfaction with a partner was strongly associated with the decision to stop childbearing at the current parity. On the other hand, cohabiting status induced uncertainty to third-birth intentions among women who desired to have three or more children.

We observed that the woman's employment status between her first and second birth had no influence on her third-child plans, since the work-oriented women intended to have a third birth as often as women who were home-oriented. Another interesting finding was that respondents who appreciated the content of the work intended to have a third child more often than respondents who considered the salary or the steadiness of the employment the most important aspect of work. Hence, satisfaction received from a career seemed not to be alternative or substitutable to children and family-life for Finnish two-child mothers. These findings support previous results from the other Nordic countries, according to which professional employment and generally stronger preference for work are not crucial determinants of third-child fertility (Hoem and Hoem 1989; Hoem 1993; Kravdal 1992).

As Rindfuss and coworkers (1996) have argued, to the extent that the labor market becomes more compatible with childrearing, employment possibilities will probably matter less in women's fertility decisions. During the past decades, one main goal of Finnish social policies has been to enhance gender equality by improving 
women's position in the labor market (Forssén 1998). In light of our findings, it appears that during the late 1980s, family policies were successful in facilitating women's possibilities of combining both career and childbearing.

Our results indicate that situational factors were of great importance in terms of the certainty of the respondents' third-birth decisions. We found that an unfavorable financial situation and dissatisfaction with the level of economic support to families with children were significantly associated with women's opinion that they could change their minds about the decision to stop childbearing. We also obtained evidence that respondents who had experienced problems with their children's daycare were more prepared than the other respondents to reverse their negative intention and decide to have a third birth. On the other hand, dissatisfaction with the level of family benefits was strongly associated with the uncertainty of a positive intention - this was the case also among respondents who wished to have at least three children. Moreover, an unsatisfactory economic situation seemed to deter women from realizing their family-size preferences. These results suggest that there are external - particularly economic - constraints, which limit the fertility of twochild mothers who might have a third child if the circumstances were different. For these women, a reduced family-size may indicate feelings of having little control over the external environment. In this respect, our results support Morgan's (1982) reasoning, according to which period-specific factors, such as socio-economic circumstances and a particular society's social policies, probably have a significant role in determining the actual childbearing behavior of the uncertain couples.

The general finding of the study was that familial, situational, and attitudinal factors all have significant independent effects on the decision to have a third child. Our results suggest, however, that the factors that push women to have a third birth differ from those that predict the certainty of the third-birth intention. In accordance with our interpretation, mainly interpersonal and attitudinal attributes determine the decision to continue childbearing after two children or to stop at parity two. However, non-motivational features, especially those related to social and economic life circumstances, may be perceived as obstacles to further childbearing, and thus may introduce uncertainty to future childbearing plans, or even prevent families from realizing their family-size desires.

* Previous versions of this manuscript were presented at the European Population Conference in The Hague, Netherlands, August 1999, and in the meeting of the Population Association of America in Los Angeles, March 2000. Support for this research was provided by the Finnish Graduate School of Social Sciences, the Population, Health, and Living Conditions program, and the Academy of Finland. We are grateful to an anonymous referee and the participants of the graduate school seminars for comments on previous versions of this manuscript. 


\section{References}

Axinn, William J., Marin E. Clarkberg and Arland Thornton. 1994. Family influences on family size preferences. Demography 31(1): 65-79.

Beckman, Linda. 1978. Couple's decision-making processes regarding fertility. In: Social demography, edited by Karl E. Taeuber, Larry L. Bumpass, and James A. Sweet. New York: Academic Press.

Berinde, Diana. 1999. Pathways to a third child in Sweden. European Journal of Population 15: 349-378.

Brien, Michael J., Lee A. Lillard, and Linda J. Waite. 1999. Interrelated family-building behaviors: Cohabitation, marriage, and nonmarital conception. Demography 36 (4): 535551.

Coleman, David. 1996. New patterns and trends in European fertility: International and sub-national comparisons. In: Europe's population in the 1990's, edited by David Coleman. Oxford: Oxford University Press.

Eurobarometer. 1990. The family and the desire for children. Commission of the European Communities, Eurobarometer 32.

Forssén, Katja. 1998. Children, families and the welfare state. Studies on the outcomes of the Finnish family policy. National research and development centre for welfare and health, Research report 92. Jyväskylä: Gummerus Printing.

Hechter, Michael, James Ranger-Moore, Guillermina Jasso, and Christine Horne. 1999. Do values matter? An analysis of advance directives for medical treatment. European Sociological Review 15 (4): 405-430.

Hoem, Britta and Jan M. Hoem. 1989. The impact of women's employment on second and third births in modern Sweden. Population Studies 43 (1): 47-67.

Hoem, Britta. 1993. The compatibility of employment and childbearing in contemporary Sweden. Acta Sociologica 36: 101-120.

Hoem, Britta. 1996. The social meaning of age for third-birth fertility: A methodological note on the need to sometimes respecify an intermediate variable. Yearbook of Population Research in Finland 33: 333-339.

Hosmer, David W. and Stanley Lemeshow. 1989. Applied logistic regression analysis. New York: John Wiley \& Sons.

Kartovaara, Leena. 1999. Boy or girl? Does it matter and is it a coincidence or destiny? Paper presented at the European Population Conference, September 1999. The Hague.

Keinänen, Päivi. 1994. Perheet työelämässä (Families in working life). In: Suomalainen perhe (The Finnish family). Statistics Finland, Population 1994:5. Helsinki: Statistics Finland.

Kravdal, Øysten. 1992. The weak impact of female labor force participation on Norwegian third-birth rates. European Journal of Population 8 (3): 247-263.

Lesthaeghe, Ron and Guy Moors. 1996. Living arrangements, socio-economic position, and values among young adults. In: Europe's population in the 1990's, edited by David Coleman. Oxford: Oxford University Press.

Lilliard, Lee A. and Linda J. Waite. 1993. A joint model of marital childbearing and marital disruption. Demography 30 (4): 653-681.

Miller, Warren B. and David J. Pasta. 1993. Motivational and nonmotivational determinants of child-number desires. Population and Environment 15 (2): 113-138.

Miller Warren B. and David J. Pasta. 1995. Behavioral intentions: Which ones predict fertility behavior in married couples? Journal of Applied Social Psychology 25 (6): 530 555. 
Monnier, Alain. 1989. Fertility intentions and actual behaviour. A longitudinal study: 1974, 1976, 1979 Population: English Selection 44 (1): 237-260.

Morgan, S. Philip. 1981. Intention and uncertainty at later stages of childbearing: The United States 1965 and 1970. Demography 18 (3): 267-285.

Morgan, S. Philip. 1982. Parity-specific fertility intentions and uncertainty: The United States, 1970 to 1976. Demography 19 (3): 315-334.

Namboodiri, Krishnan N. 1983. Sequential fertility decision-making and the life course. In: Determinants of fertility in developing countries, Vol. 2, edited by Rodolfo A. Bulatao, Ronald D. Lee with Paula E. Hollerbach, and John Bongaarts. New York: Academic Press.

NCHS (National Center for Health Statistics). 1997. Fertility, family planning, and women's health: New data from the 1995 National Survey of Family Growth. Vital and Health Statistics 23 (19).

Palomba, Rossella and Hein Moors. 1995. Attitudes towards marriage, children, and population policies in Europe. In: Population, family, and welfare. A comparative survey of European attitudes, Vol. 1, edited by Hein Moors and Rossella Palomba. Oxford: Clarendon Press.

Rindfuss, Ronald R., Karin L. Brewster and Andrew L. Kavee. 1996. Women, work, and children: Behavioral and attitudinal change in the United States. Population and Development Review 22 (3): 457-482.

Rønsen, Marit. 1998. Fertility and public policies - evidence from Norway and Finland. Statistics Norway series, Documents 98/12.

Schoen, Robert, Young J. Kim, Constance A. Nathanson, Jason Fields, and Nan Marie Astone. 1997. Why do Americans want children? Population and Development Review 23 (2): 333-358.

Schoen, Robert, Nan Marie Astone, Young J. Kim, Constance A. Nathanson, and Jason M. Fields. 1999. Do fertility intentions affect fertility behavior? Journal of Marriage and the Family 61: 790-799.

Sloane, Douglas M. and Che-Fu Lee. 1983: Sex of previous children and intentions for further births in the United States, 1965-1976. Demography 20 (3): 353-367.

Thomson, Elizabeth. 1997. Couple childbearing desires, intentions, and births. Demography 34 (3): 343-354.

Thomson, Elizabeth and Jan M. Hoem. 1998. Couple childbearing plans and births in Sweden. Demography 35 (3): 315-322.

Van den Akker, Piet, Loek Halman, and Ruud De Moor. 1993. Primary relations in western societies. In: The individualizing society, value change in Europe and North America, edited by Peter Ester, Loek Halman, and Ruud de Moor. Tilburg: Tilburg University Press.

Vikat, Andres, Elizabeth Thomson, and Jan M. Hoem. 1999. Stepfamily fertility in contemporary Sweden: The impact of childbearing before the current union. Population Studies 53 (2): 211-225.

White, Lynn K. and Kim Hyunju. 1987. The family-building process: Childbearing choices by parity. Journal of Marriage and the Family 49: 271-279.

Wu, Zheng and Hui Wang. 1998. Third birth intentions and uncertainty in Canada. Social Biology 45 (1-2): 96-112.

Yamaguchi, Kazuo and Linda R. Ferguson. 1995. The stopping and spacing of childbirths and their birth-history predictors: Rational-choice theory and event-history analysis. American Sociological Review 60 (2): 272-298. 